\title{
Measuring The Effects \\ Of Financial Liberalization On The Supply Of Credit To The Private Sector: The Case Of Lebanon
}

Viviane Y. Naïmy, (Email: VNaimy@ndu.edu.lb), Notre Dame University, Lebanon

\begin{abstract}
The purpose of this paper is to build a systematic analysis of financial liberalization. An integrated model of portfolio decision-making and consumption-saving decision is presented in order to detect the effect of financial liberalization on the supply of credit to the private sector. Moreover, the crowding out of the private sector credit by the Lebanese government sector is illustrated through the identification of the gap between the demand for money of the public and private sectors.
\end{abstract}

\section{INTRODUCTION}

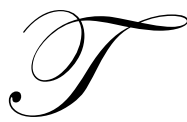

he restriction of loans to a few large borrowers, together with the widespread existence of high inflation, growing budget deficit, and reduced real interest rates, led to a serious Lebanese credit crunch since 1994. The present recession is exposing the frailty of the Lebanese commercial banks' loans: the loan-loss reserve to total assets and the delinquency rates are increasing since 1998. With reduced real interest rates on savings deposits and expectations of continued inflation, it is not surprising that few individuals are willing to save.

In addition, the Lebanese commercial banks are subject to numerous lending restrictions and are facing "disguised" mandatory interest rate ceilings on loanable funds. These artificial interest rates are often set by the Lebanese government always seeking to finance its budget deficit through the sale of bonds to commercial banks. Consequently, these banks had to resort to rationing the available credit, where the demand for loanable funds greatly exceeds the available supply - a phenomenon known as financial repression ${ }^{1}$ because investment in Lebanon is repressed by a shortage of savings, which in turn results from administered real interest rates ${ }^{2}$. In the absence of outright corruption in the allocation of loanable funds, most commercial banks choose to allocate the available credit to a few large borrowers so as to minimize their "burden". Hence, small farmers and urban entrepreneurs have no recourse but to seek finance from the unorganized money market, where they are willing to pay above -marketclearing rates ${ }^{4}$.

One suggested solution to this problem is to liberalize the financial sector by allowing nominal interest rates to reach the market-clearing-levels. This would cause real interest rates to increase and thus remove the explicit interest rate subsidy accorded to preferred borrowers who are powerful enough to have access to the "rationed credit"

\footnotetext{
${ }^{1}$ This is in addition to the changes in the reserve requirements.

${ }^{2}$ Usually set at below market-clearing levels.

${ }^{3}$ Where "burden" represents the net noninterest income.

${ }^{4}$ Naimy V. (2004), "Financing Problems Faced By The Lebanese SMEs: An Empirical Study". The International Business And Economics Research Journal, Volume 3, Number 1, January, p. 27-38
} 
and should generate more domestic savings and investment. However, evidence of the effects of financial reform on savings and investment may reveal shortcomings on the process 5 .

As no academic work measuring the effects of financial liberalization on the supply of credit to the private sector has been done in Lebanon, this paper tries to fill this gap by using an integrated model of portfolio selection and consumption-saving. The particularity of this model resides in the fact that it incorporates simultaneously the role of wealth effects, portfolio changes effects, and the crowding out effects. Moreover, based on Gupta K. and Lensink R. $(1996)^{6}$ works, we consider the government budget deficit as endogenous in order to better illustrate the effects of interest rate deregulation on government expenditures, revenues, and interest payment. Then, and within the context of the Lebanese financial system, we try to apply this model using a variety of assumptions in order to carry out some relevant conclusions related to the crowding out effects.

\section{BUILDING THE MODEL}

\section{Conceptual Issues}

The seminal works of McKinnon (1973) ${ }^{7}$ and Shaw $(1973)^{8}$ predict that interest rate controls and directed credit programs impede the process of deepening. In contrast, there is a small but growing literature which emphasizes financial market imperfections, including asymmetric information and imperfect competition (Stiglitz (1994) ${ }^{9}$, Caprio $(1994)^{10}$, Gertler and Rose (1996) ${ }^{11}$, Hellmann et al. $(1996 \mathrm{a}, \mathrm{b}, 2000)^{12}$. Besides these macroeconomics approaches, there are also models belonging to the literature on banking that investigate the effects of financial regulation on risk taking by banks (Kim and Santomero $(1988)^{13}$, Keely and Furlong $(1990)^{14}$, and Gennote and Pyle $(1991)^{15}$. Recently, the empirical literature on the effects of financial policies has been growing rapidly. Most of the macro-econometric studies focus on a number of Asian Economies and show that the effects of financial restraints may be very large but

\footnotetext{
${ }^{5}$ Such as the case of Chile during the 1970s where the acquisition of numerous banks by large conglomerates, or grupos, occurred. These grupos used their financial resources to buy recently privatized firms or to expand their companies. When many of their firms faced financial losses, these grupos had to resort to additional funding to avoid bankruptcy. Hence the Chilean financial system was very vulnerable when the debt crisis struck in the 1980s.

${ }^{6}$ Gupta K. and Lensink R. (1996). "Financial Liberalization and Investment", Routledge Studies in Development Economics, British Library cataloguing in Publication Data.

${ }^{7}$ McKinnon R., (1973). Money and Capital in Economic Development. Brookings Institution, Washington DC.

${ }^{8}$ Shaw E., (1973). Financial Deepening in Economic Development. Oxford University Press, New York.

${ }^{9}$ Stiglitz JE. (1994). "The Role of the State in Financial Markets." Proceedings of the World Bank Annual Conference on Development Economics 1993, 19-52.

${ }^{10}$ Caprio G. (1994). "Banking on Financial Reform? A case of Sensitive Dependence on Initial Conditions." In Financial Reform: Theory and Experience, Caprio G, Atiyas I., Hanson J. (eds). Cambridge University Press. Without the work of Gupta K. and Lensink R., the theoretical part of this research would have been impossible and would have taken years of work.

${ }^{11}$ Gertler M., Rose A (1996). "Finance, Public Policy and Growth". In Financial Reform: Theory and Experience, Caprio G, Atiyas I., Hanson J. (eds). Cambridge University Press.

${ }^{12}$ Hellman T., Murdock K., Stiglitz JE., (1996a). "Financial Restraint: Toward A New Paradigm". In The Role Of Government In East Asian Economic Development: Comparative Institutional Analysis, Aoki M., Okuno-Fujiwara M., Kim H (eds). Oxford University Press: Oxford.

Hellman T., Murdock K., Stiglitz JE., (1996b). “Deposit Mobilisation Through Financial Restraint”..In Financial Development and Economic Growth, Hermes N., Lensink R (eds). Routlege: London.

Hellman T., Murdock K., Stiglitz JE., (2000). "Liberalization, Moral Hazard in Banking, and Prudential Regulation: Are Capital Requirements Enough?” American Economic Review 90: 147-165

${ }^{13}$ Kim D and Santomero A., (1998). "Risk in Banking and Capital Regulation". The Journal of Finance XLIII:12191233

${ }^{14}$ Keely M., and Furlong F., (1990). "A reexamination of Mean-Variance Analysis of Bank Capital Regulation". Journal Of Banking and Finance 14: 69-84.

${ }^{15}$ Gennote G., and Pyle D., (1991). "Capital Controls and Bank Risk”. Journal of Banking and Finance 15:805-824.
} 
vary considerably across countries ${ }^{16}$. Cross-country growth regressions indicate that financial restraints ${ }^{17}$ may hamper financial development (Rossi 1999) ${ }^{18}$.

\section{The Model}

This model, based on the work of Gupta K. and Lensink R. (1996) ${ }^{19}$, considers a private sector (PS), a banking sector including the central bank (CB) and the private banks (PB), a government sector (GS), and an external sector (ES). The supply side related to the ES is ignored in our study. This model highlights the implications of the consumption-saving decision and the portfolio allocation decision where both are jointly determined. Table 1 illustrates the structure of the model.

Table 1: Structure of the Model

\begin{tabular}{|l|c|c|c|c|c|c|}
\hline & 1. PS & 2. CB & 3. PB & 4. GS & 5. ES & Total \\
\hline Non-financial transactions & $C p+\Delta k-(y-T)$ & & & $C g+I g-T$ & $\mathrm{NE}^{20}$ & 0 \\
\hline Bonds & $\Delta b$ & & & $-\Delta b$ & & 0 \\
\hline Deposits & $\Delta m$ & & $-\Delta m$ & & & \\
\hline Foreign Assets & $\Delta f$ & & & $-\mathrm{A}$ & $-\Delta f+A$ & 0 \\
\hline Loans & $-\Delta L p$ & $\Delta L g-\Delta R$ & $\Delta L p+\Delta R$ & $-\Delta L g$ & & 0 \\
\hline Total & 0 & 0 & 0 & 0 & 0 & 0 \\
\hline
\end{tabular}

\section{The Private Sector (PS)}

This consolidated $^{21}$ sector is constituted of firms and households. This consolidation may suffer from certain shortcomings. For example, it would be interesting to see if the crowding out effects are confined to households or to firms. If the crowding out effects are confined to firms, investment will be affected not only from the demand side but also from the supply side ${ }^{22}$. However, disaggregating this sector requires the set up of a very complicated mechanism that distributes this effect on the two components which is impossible to apply for the Lebanese case. It's worth mentioning that the choice of consolidating this sector is justified by the purpose of this study which is to illustrate and measure the effects of the public debt (the government borrowing from the banking sector) and its crowding out effects.

The budget constraint of this sector is given by column 1 of table 1 :

$y-T+\Delta L_{p}=y d+\Delta L_{p}=C p+\Delta_{m}+\Delta_{k}+\Delta_{b}+\Delta_{f}$

${ }^{16}$ Demetriades P., and Luintel K., (1997). "The Direct Cost of Financial Repression: Evidence from India". The Review of Economics and Statistics 106: 359-374

${ }^{17}$ With perhaps the exception of controls on capital outflows.

${ }^{18}$ Rossi M., (1999). "Financial Fragility and Economic Performance in Developing Economies - Do Capital Controls, Prudential Regulation, and Supervision Matter?" IMF Working Paper, WP/99/66, International Monetary Fund: Washington, DC.

${ }^{19}$ P. 11-21

${ }^{20} \mathrm{NE}$ stands for net exports

${ }^{21}$ The issue of consolidation is very meticulous. Depending on the purpose of the research, one may argue that the disaggregation of the consolidated sector into its components would be more desirable as suggested by Bourguignon et al. (1992) in their study of the effects of structural adjustment programs on income distribution where they imposed restrictions that cannot be applied in our study. For example, they assume that households are not liquidity constrained and that not only is the consumption-saving decision independent of the portfolio selection decision, but that the latter is also sequential in terms of the liquidity of the assets.

Bourguignon F., Branson W.H., et De Melo J., (1992). “Adjustment and Income Distribution: A Micro-Macro Model for Counterfactual Analysis.” Journal of Development Economics, 38: 17-39

${ }^{22}$ Please refer to the simulation results of Gupta K. and Lensink R. (1996), chapter 7. 
The variables constituting the portfolio represent four assets:

bank deposits: $m$

real government bonds: $b$

real physical capital: $k$

inflation hedge where foreign assets are represented by $f$ and denominated in domestic currency.

$C_{p}$ represents real private consumption,

$L_{p}$ stands for real private credit,

$y$ for real GDP

$T$ for taxes, and

$y_{d}$ for real disposable income assumed to be exogenous ${ }^{23}$.

With respect to Barro $(1984)^{24}$, the model considers that investment takes place in this sector and thus justifies the budget constraint. Based on Gupta K. (1996) work, the behavioral equations for the private sector are presented as follows:

$\Delta_{m}=\alpha_{1} y_{d}+\alpha_{2} W+\alpha_{3} \Delta L_{\mathrm{p}}+\alpha_{4} i_{\mathrm{m}}-\alpha_{5} i_{\mathrm{k}}-\alpha_{6} i_{\mathrm{b}}-\alpha_{7} i_{\mathrm{f}}-\alpha_{8} \pi^{\mathrm{e}}$

$\Delta_{\mathrm{k}}=\alpha_{11} y_{d}+\alpha_{12} W+\alpha_{13} \Delta L_{\mathrm{p}}-\alpha_{14} i_{\mathrm{m}}+\alpha_{15} i_{\mathrm{k}}-\alpha_{16} i_{\mathrm{b}}-\alpha_{17} i \mathrm{f}-\alpha_{18} \pi^{\mathrm{e}}$

$\Delta_{\mathrm{b}}=\alpha_{21} y_{d}+\alpha_{22} W+\alpha_{23} \Delta L_{\mathrm{p}}-\alpha_{24} i_{\mathrm{m}}-\alpha_{25} i_{\mathrm{k}}+\alpha_{26} i_{\mathrm{b}}-\alpha_{27} i_{\mathrm{f}}-\alpha_{28} \pi^{\mathrm{e}}$

$\Delta_{\mathrm{f}}=\alpha_{31} y_{d}+\alpha_{32} W+\alpha_{33} \Delta L_{\mathrm{p}}-\alpha_{34} i_{\mathrm{m}}-\alpha_{35} i_{\mathrm{k}}-\alpha_{36} i_{\mathrm{b}}+\alpha_{37} i_{\mathrm{f}}-\alpha_{38} \pi^{\mathrm{e}}$

$\mathrm{C}_{\mathrm{p}}=\alpha_{41} y d+\alpha_{43} \Delta L_{\mathrm{p}}-\alpha_{44} i_{\mathrm{m}}-\alpha_{45} i_{\mathrm{k}}-\alpha_{46} i_{\mathrm{b}}-\alpha_{47} i_{f}-\alpha_{48} \pi^{\mathrm{e}}$

$S_{\mathrm{p}}=y_{\mathrm{d}}-C_{\mathrm{p}}$

$W=W_{-1}+S_{\mathrm{p}}$

$\mathrm{i}_{\mathrm{m}}, \mathrm{i}_{\mathrm{k}}, \mathrm{i}_{\mathrm{b}}$, and $i_{\mathrm{f}}$ are the exogenous nominal rates of return on deposits, physical capital, government bonds, and foreign assets respectively.

$S_{\mathrm{p}}=$ real private savings,

$W=$ real private wealth,

$\pi^{e}=$ exogenous expected rate of inflation.

Using the taxonomy introduced by Brillembourg $(1978)^{25}$, we differentiate three possible reactions to portfolio disequilibrium which would be caused by the liberalization of interest rates leading to excess demand for bank deposits.

- a reallocation of the existing portfolio,

- a reallocation of a given aggregate of savings by changing the menu of assets, and

- a change in the aggregate flow of savings which, assuming that bank deposits are a normal good, will increase their demand.

\footnotetext{
${ }^{23}$ Real disposable income equals y minus taxes plus net interest receipts. For simplicity we ignore net interest receipts since an increase in the deposit rate normally leads to an increase in the lending rate which affects net interest receipts in opposite directions. In this model we assume that real non-interest income is not influenced by changes in the deposit rate. This assumption is the result of the not taking into consideration the supply side. This implies that real disposable income is exogenous and hence not influenced by changes in the deposit rate.

Morisset J., (1993). "Does Financial Liberalization Really Improve Private Investment in Developing Countries?" Journal of Developing Economics, 40:133-150.

${ }_{24}^{24}$ Barro R., (1984). Macroeconomics, Wiley, New York.

${ }^{25}$ Brillembourg A., (1978). "The Role of Savings in Flow Demand for Money: Alternative Partial Adjustment Models.” Staff Paper FMI, 25:278-292.
} 
In this model, only reactions 1 and 3 are incorporated. For this purpose, and based on the model of Owen $(1981)^{26}$, which is based on the works of Brainard and Tobin $(1968)^{27}$, Smith $(1978)^{28}$, and Pissarides $(1978)^{29}$, we use the integrated model of portfolio selection and consumption-saving decisions.

The justification of the behavioral equations is illustrated in table 2 .

Table 2

\begin{tabular}{|c|c|c|c|}
\hline $\begin{array}{l}\text { Equations' } \\
\text { identification }\end{array}$ & Justification & Reference & Coefficients' Sign \\
\hline $\begin{array}{l}2,3,4 \text { and } 5: \\
\text { Asset demand } \\
\text { equations }\end{array}$ & $\begin{array}{l}\text { Derived from using the multivariate } \\
\text { adjustment function where changes in } \\
\text { wealth (W) enter as a separate explanatory } \\
\text { variable, which allows us to incorporate } 1 \\
\text { and } 2 \text { defined above. }\end{array}$ & $\begin{array}{l}\text { Brainard and } \\
\text { Tobin (1968) }\end{array}$ & $\begin{array}{l}\text { Coefficients of disposable income and wealth } \\
\text { are positive in each case }{ }^{31} \text {. The coefficients of } \\
\Delta L_{\mathrm{p}} \text { are also positive. The asset demands are } \\
\text { assumed to be positively affected by the own } \\
\text { rates of return and negatively by the } \\
\text { alternative one, implying that the assets are } \\
\text { gross substitutes. }\end{array}$ \\
\hline $\begin{array}{l}\text { 6: The } \\
\text { consumption } \\
\text { function }\end{array}$ & $\begin{array}{l}\text { Does not include wealth }{ }^{32} \text { or lagged } \\
\text { values }^{33} \text { of the various assets. }\end{array}$ & Owen (1981) & $\begin{array}{l}\text { It is assumed that } 0<\alpha_{41}<1 \text { and } \alpha_{43}>0 \text {. } \\
\text { With respect to the interest rates, it is assumed } \\
\text { that the negative substitution effect exceeds } \\
\text { the positive income effect. }\end{array}$ \\
\hline $\begin{array}{l}\text { Why } \Delta L_{\mathrm{p}} \\
\text { appears in } \\
2,3,4,5, \& 6 ?\end{array}$ & $\begin{array}{l}\Delta L_{\mathrm{p}} \text { represents liquidity constraints for } \\
\text { firms and households }{ }^{34} . \Delta L_{\mathrm{p}} \text { is treated as } \\
\text { being exogenous to the private sector. }\end{array}$ & $\begin{array}{l}\text { Fazzari S. et } \\
\text { al., }(1988)^{35} \\
\text { p. } 163 .\end{array}$ & \\
\hline 7: Savings & $y d$ is exogenously given & & \\
\hline $\begin{array}{l}\text { 8: Private } \\
\text { wealth }\end{array}$ & & & \\
\hline
\end{tabular}

${ }^{26}$ Owen P.D., (1981). "Dynamic Models of Portfolio Behavior: A General Integrated Model of Incorporating Sequential Effects". American Economic Review, 71:231-238.

${ }^{27}$ Brainard W.C., et Tobin J., (1968). "Pitfalls in Financial Model Building" American Economic Review, 58: 99-122.

${ }^{28}$ Smith G., (1978). "Dynamic Models of Portfolio Behavior: Comment on Purvis." American Economic Review, 68:410-416.

${ }^{29}$ Pissarides C.A., (1978). "Liquidity Considerations in the theory of Consumption." Quarterly Journal of Economics 93: 279-296.

${ }^{30}$ These equations do not include the lagged values of the various assets as specified in the Brainard-Tobin framework, because this model does not depend on their inclusion. We have excluded them for convenience. It should be noted that their inclusion becomes necessary in case of simulation because the time-path of endogenous variables depends on their presence.

31 Implying that all assets are normal goods.

${ }^{32}$ According to Owen (1981), the exclusion of wealth is assumed based on the fact that the "end of period wealth" is a consequence of the consumption-saving decision and not a determinant of it.

${ }^{33}$ The exclusion of the lagged asset terms, although present in the Owen model, is justified for the same reasons as in the asset equation.

${ }^{34}$ There is considerable evidence that households face such constraints in developing countries caused by the presence of inefficient credit markets (Rosenzweig M. R., et Wolpin K.I., (1993)).

The presence of the credit variable in the consumption equation is meant to capture the role of such market imperfections (Jappelli T. et Pagano M., (1994)).

Rosenzweig M. R., and Wolpin K.I., (1993). "Credit Market Constraints, Consumption Smoothing and the Accumulation of Durable Production, Assets in Low-Income Countries: Investment in Bullocks in India." Journal of Political Economy, 101(2):223-244.

Jappelli T. et Pagano M., (1994). "Savings, Growth and Liquidity Constraints." Quarterly Journal of Economics, 109(1) : 83-109

${ }^{35}$ Fazzari S. M., Hubbard R.G., and Peterson B.C., (1988). "Financial Constraints and Corporate Investment." Brooking Papers on Economic Activity, (19): 141-195. 
The next step is to derive the adding-up restrictions of the above sub-model. It can be shown that (1) is satisfied if and only if the following holds:

$\left(\alpha_{1}+\alpha_{11}+\alpha_{21}+\alpha_{31}\right)+\alpha_{41}\left(1-\alpha_{2}-\alpha_{12}-\alpha_{22}-\alpha_{32}\right)+\left(\alpha_{2}+\alpha_{12}+\alpha_{22}+\alpha_{32}\right)=1$
$\left(\alpha_{3}+\alpha_{13}+\alpha_{23}+\alpha_{33}\right)+\alpha_{43}\left(1-\alpha_{2}-\alpha_{12}-\alpha_{22}-\alpha_{32}\right)=1$
$\left(\alpha_{4}-\alpha_{14}-\alpha_{24}-\alpha_{34}\right)-\alpha_{44}\left(1-\alpha_{2}-\alpha_{12}-\alpha_{22}-\alpha_{32}\right)=0$
$\left(-\alpha_{5}+\alpha_{15}-\alpha_{25}-\alpha_{35}\right)-\alpha_{45}\left(1-\alpha_{2}-\alpha_{12}-\alpha_{22}-\alpha_{32}\right)=0$
$\left(-\alpha_{6}-\alpha_{16}+\alpha_{26}-\alpha_{36}\right)-\alpha_{46}\left(1-\alpha_{2}-\alpha_{12}-\alpha_{22}-\alpha_{32}\right)=0$
$\left(-\alpha_{7}-\alpha_{17}-\alpha_{27}-\alpha_{37}\right)-\alpha_{47}\left(1-\alpha_{2}-\alpha_{12}-\alpha_{22}-\alpha_{32}\right)=0$
$\left(-\alpha_{8}-\alpha_{18}-\alpha_{28}-\alpha_{38}\right)-\alpha_{48}\left(1-\alpha_{2}-\alpha_{12}-\alpha_{22}-\alpha_{32}\right)=0$

The symmetry restrictions require that:

$$
\begin{aligned}
& \alpha_{5}=\alpha_{14} \\
& \alpha_{6}=\alpha_{24} \\
& \alpha_{7}=\alpha_{34} \\
& \alpha_{16}=\alpha_{25} \\
& \alpha_{17}=\alpha_{35} \\
& \alpha_{27}=\alpha_{36}
\end{aligned}
$$

\section{The Banking Sector (BS)}

The central bank and the commercial banks are consolidated into a single sector. The budget constraint can be derived from consolidating column 2 and 3 in table 1 as follows:

$\Delta L_{\mathrm{p}}+\Delta L_{\mathrm{g}}=\Delta_{\mathrm{m}}$

$\Delta L_{\mathrm{g}}$ denotes bank credit for the government sector ${ }^{36}$. Given $\Delta L_{\mathrm{g}}$ and $\Delta_{\mathrm{m}}$, the supply of credit to the private sector is residually determined. There is no equation for the demand for loans from the private sector since it is assumed that this sector is credit constrained ${ }^{37}$.

Equation 10 illustrates how the McKinnon-Shaw mechanism would work. Assume that $\Delta L_{\mathrm{g}}$ remains constant and that the demand for deposits $(m)$ goes up in response to liberalization of interest rate on deposits. This would mean an increase in credit to the private sector. Since $\alpha_{13}>0$ (in equation 3), this would mean an increase in private investment. In other word, a given increase in $i_{\mathrm{m}}$ would lead to an increase in the demand for $m$ as well as $k$, thus confirming the "complementarity" hypothesis.

\section{The Government Sector (GS)}

The government budget constraint ${ }^{38}$ is given in column 4 of table 1 as follows:

$C_{g}+I_{g}-T=D E F=\Delta L_{\mathrm{g}}+\Delta_{\mathrm{b}}+A$

$C_{\mathrm{g}}=$ government consumption

$I_{\mathrm{g}}=$ government investment

$A=$ foreign aid

$D E F=$ government deficit

\footnotetext{
${ }^{36}$ Net interest receipts are ignored (the change in real bank profits) since, according to Morisset (1993), the change in real bank profits is not influenced by changes in the deposit rate.

${ }^{37}$ That's why it is treated as being exogenous in the private sector's budget constraint.

${ }^{38}$ This budget constraint says that a given deficit is financed by borrowing from the banking sector and/or by selling bonds to the non-bank private sector and/or by foreign aid.
} 
It is assumed that a change in the deposit rate does not affect government deficit. Hence, we consider government expenditures and taxes to be exogenous. Foreign aid is also assumed to be exogenous.

A one dollar reduction in the demand for government bonds, given $A$, means a one dollar increase in the government borrowing from the banking sector. The increase in government borrowing from the banking sector is determined by the budget constraint of this sector. This explains how a crowding out of the private sector credit may occur if the government ${ }^{39}$ has to borrow from the banking sector.

\section{IMPACT OF FINANCIAL LIBERALIZATION ON THE SUPPLY OF CREDIT TO THE LEBANESE PRIVATE SECTOR}

\section{Overview Of The Lebanese Economic Situation}

Table 3 shows some basic data for the Lebanese economy for the years 1991 to 2000. Nominal GDP (in US\$) grew at annual average rate of 12 percent over this period but inflation cut real growth considerably to 4.2 percent per annum (excluding 1991). During 2000, although the inflation rate was down to zero percent (from 120 percent in 1992), real GDP growth also was zero percent. During the 1990s and continuing today, the Lebanese economy faces challenges with respect to (1) government-budget deficits, (2) current-account deficits, (3) high interest rates, and (4) high unemployment.

Table 3: Economic Growth in Lebanon

\begin{tabular}{|c|c|c|c|c|c|}
\hline Year & $\begin{array}{c}\text { GDP (Trillions of } \\
\text { Lebanese } \\
\text { Pounds) }\end{array}$ & $\begin{array}{c}\text { GDP (Equivalent } \\
\text { in Billions of } \\
\text { US\$) }\end{array}$ & $\begin{array}{c}\text { Average } \\
\text { Exchange Rate } \\
\text { (Cost of US\$ in } \\
\text { LP) }\end{array}$ & $\begin{array}{c}\text { Real GDP } \\
\text { Growth }\end{array}$ & $\begin{array}{c}\text { Inflation Rate } \\
\text { (GDP Deflator) }\end{array}$ \\
\hline 1991 & 4.1 & 4.5 & 928 & $38.2 \%$ & $51.5 \%$ \\
\hline 1992 & 9.5 & 5.5 & 1,713 & $4.5 \%$ & $120.0 \%$ \\
\hline 1993 & 13.1 & 7.5 & 1,741 & $7.0 \%$ & $29.1 \%$ \\
\hline 1994 & 15.3 & 9.1 & 1,680 & $8.0 \%$ & $8.0 \%$ \\
\hline 1995 & 18.0 & 11.1 & 1,621 & $6.5 \%$ & $10.6 \%$ \\
\hline 1996 & 20.4 & 13.0 & 1,571 & $4.0 \%$ & $8.9 \%$ \\
\hline 1997 & 22.9 & 14.8 & 1,539 & $4.0 \%$ & $7.7 \%$ \\
\hline 1998 & 24.5 & 16.2 & 1,516 & $3.0 \%$ & $4.0 \%$ \\
\hline 1999 & 24.8 & 16.4 & 1,508 & $1.0 \%$ & $0.2 \%$ \\
\hline 2000 & 24.8 & 16.4 & 1,508 & $0 \%$ & $0 \%$ \\
\hline
\end{tabular}

Source: Banque du Liban, "Financial Markets Handbook"

Moreover, the Lebanese public infrastructure was badly damaged during the civil war. In the years following the conflict, the government incurred large capital expenditures, financed mainly by issuing treasury bills and notes rather than by taxes. Since 1994, deficits have been around LP 3 trillion (equivalent to US $\$ 2$ billion) every year. Even though capital expenditures have been reduced, the government is making substantial interest payments on its accumulated debt. The current net total debt ${ }^{40}$ of Lebanon exceeds 185 percent of the nation's gross domestic product.

These large government borrowings have put substantial pressures on financial markets. To induce investors to buy treasury bills and notes, the Lebanese government offers high interest rates on its debt obligations. Table 4 shows that the yield on three-month treasury bills has averaged 14.6 percent while the yield on two-year treasury notes has averaged 19.29 percent for the years 1993 to 2000. The average rate on all treasury obligations has declined,

\footnotetext{
${ }^{39}$ It is assumed that the government fixes the interest rate on its bonds and the quantity of the bonds sold is then entirely determined by the non-bank private sector's portfolio selection behavior.

${ }^{40}$ Naïmy V. (2004). "A proposed Restricting of Lebanese Public Debt To Promote Economic Growth". The International Business And Economics Research Journal, Volume 3, Number 8, p. 15-25
} 
however, dropping from 21.4 percent in 1993 to 12.07 percent in 2000 . The combined effects of high interest rates, rising wages, and a currency that has risen vis-à-vis its major trading partners, has dampened real economic growth over the past few years. Although inflation has slowed down considerably, the economy is still experiencing substantial unemployment.

Table 4: Summary of Lebanese Pound (LP) / US Dollar Exchange Rates, Average Yields on Various Financial Instruments and Inflation Rates, 1993-2000

\begin{tabular}{|c|c|c|c|c|c|c|c|c|}
\hline Variable & 1993 & 1994 & 1995 & 1996 & 1997 & 1998 & 1999 & 2000 \\
\hline LP/US\$ Exchange Rate at end of year & 1,711 & 1,647 & 1,596 & 1,552 & 1,527 & 1,508 & 1508 & 1508 \\
\hline Average Rates on 3 months t-bills (in LP) \% & 18.70 & 15.09 & 18.88 & 15.19 & 13.42 & 12.70 & 11.57 & 10.88 \\
\hline Average Rates on 6 months t-bills (in LP) \% & 19.94 & 17.21 & 20.65 & 16.93 & 14.30 & 13.78 & 12.74 & 11.43 \\
\hline Average Rates on 12 months t-bills (in LP) \% & 21.42 & 18.67 & 24.59 & 17.88 & 15.25 & 15.17 & 14.38 & 11.84 \\
\hline Average Rates on 24 months t-bills (in LP) \% & 25.32 & 19.23 & 23.36 & 22.79 & 16.83 & 16.72 & 15.89 & 14.14 \\
\hline Average Rate on T-bills (in LP) $\%$ & 21.35 & 17.55 & 21.87 & 18.2 & 14.95 & 14.59 & 13.65 & 12.07 \\
\hline Average Rates On Bank Deposits in LP \% & 12.78 & 13.16 & 15.14 & 14.71 & 12.68 & 12.97 & 11.94 & 10.68 \\
\hline Average Discount and Loans Rates in LP \% & 28.53 & 23.88 & 24.52 & 25.21 & 20.29 & 20.24 & 19.48 & 18.15 \\
\hline $\begin{array}{l}\text { Spread Between Average Rates on t-bills and } \\
\text { Rates on Deposits (in LP) } \%\end{array}$ & 8.57 & 4.39 & 6.73 & 3.49 & 2.27 & 1.62 & 1.71 & 1.39 \\
\hline $\begin{array}{l}\text { Spread Between Average Rates on Discount } \\
\text { and Loans and Average Rates on Deposits in } \\
\text { LP \% }\end{array}$ & 15.75 & 10.72 & 9.38 & 10.50 & 7.61 & 7.27 & 7.54 & 7.47 \\
\hline Repo Rate (in LP) \% & 31.61 & 30.00 & 43.75 & 27.83 & 27.08 & 30.00 & 27.92 & 20.83 \\
\hline Inter-Bank Rate in LP \% & 6.60 & 7.33 & 34.88 & 11.19 & 13.00 & 11.23 & 7.46 & 7.58 \\
\hline Average Discount and Loans Rates in US\$ \% & NA & NA & 12.03 & 11.91 & 11.76 & 11.54 & 10.95 & 11.19 \\
\hline Average Rates On Bank Deposits in US\$ \% & NA & NA & 5.29 & 5.41 & 5.72 & 5.89 & 5.60 & 5.92 \\
\hline $\begin{array}{l}\text { Spread Between Average Rates on Discount } \\
\text { and Loans and Average Rates on Bank } \\
\text { Deposits in US\$ \% }\end{array}$ & NA & NA & 6.74 & 6.5 & 6.04 & 5.65 & 5.35 & 5.27 \\
\hline Rate of Inflation \% & 29.1 & 8.0 & 10.6 & 8.9 & 7.7 & 4.0 & 0.2 & 0.0 \\
\hline
\end{tabular}

Lebanese banks offer loans and deposits denominated in US dollars (USD) as well as those denominated in Lebanese pounds. The average interest rates on USD loans and deposits are much lower than those denominated in LP. Table 4 shows the average USD loan and deposit rates for the years from 1995 to 2000 . $^{41}$ Rates on deposits ranged from 5.29 percent (1995) to 5.92 percent (2000) while loan rates ranged from 12.03 percent (1995) to 11.19 percent (2000).

\section{Structure Of The Lebanese Interest Rates}

The above quoted interest rates are composed of a real risk-free rate, $\mathrm{K}^{*}$, plus several premiums that reflect inflation (IP), the riskiness of the asset (such as the default risk premium (DRP), the maturity risk premium, (MRP), and the security's marketability (or liquidity, (LP))). This relationship can be expressed as follows:

Quoted interest rate $=\mathrm{K}=\mathrm{K}^{*}+\mathrm{IP}+\mathrm{DRP}+\mathrm{LP}+\mathrm{MRP}$

Based on the above analysis regarding the Lebanese public debt, the public deficit, and the high levels of interest rates, we conclude that $\mathrm{K}^{*}$ is virtual for the case of Lebanon. IP, DRP, LP, and MRP constitute the biggest share (more than 90\%) of the nominal rates. Estimating the sum of these premiums in Lebanon cannot be accurate

\footnotetext{
${ }^{41}$ The average interest rate on US dollar denominated loans and deposits were not available for 1993 and 1994.
} 
giving the present volatile economic situation that may sharply vary from year to year ${ }^{42}$. However, it's clear that real interest rates are depressed (even if the public authorities claims the opposite) which in turn is affecting adversely the economic growth.

\section{Reserve And Liquidity Requirements}

Until September 2001, banks operating in Lebanon have been required to keep $13 \%{ }^{43}$ of their deposits in LP as reserves with the Central Bank (Banque Du Liban, BDL). At the end of the same year, BDL increased the required reserve ratio to $25 \%$ of sight deposits denominated in LP and to $15 \%$ of time deposits ${ }^{44}$ denominated in LP. In addition, BDL has also introduced a new reserve required ratio of $15 \%$ on deposits ${ }^{45}$ denominated in US $\$^{46}$. Banks failing to keep such reserves will be obliged to call for and liquidate part of their loans and credits in order to attain the required reserves. Otherwise, they will be charged a penalty of $300 \%$ per anum of the value of the shortfall in the required reserves.

Regarding liquidity requirements, lending limits are imposed on USD credits with a ceiling of $70 \%$ of USD deposits. The liquidity ratio is the share of liquid assets ${ }^{47}$ to deposits and other obligations ${ }^{48}$.

Reserve and liquidity requirements in Lebanon are considered as a tax on financial intermediation, which widens the spread between deposit and loan interest rate and reduces the size of the financial system ${ }^{49}$. Hence, the abolition (or the decrease) of reserve requirements, by increasing the size of financial intermediation and removing the distortionary effects of the tax, is likely to result in a deeper financial system. This argument is implicitly based on the assumption that the Lebanese government revenue from reserve and liquidity requirements is used unproductively, to finance government consumption. If these resources are instead used to finance productive public investment, then this conclusion may not follow. Much of the literature on infrastructure demonstrates that investment in public capital has large positive effects on the productivity of private capital ${ }^{50}$. If this is the case, then reserve and liquidity requirements are likely to boost economic growth, thereby also likely to enhance financial development. Additionally, reserve and liquidity requirement policies, if applied properly, may have more direct effects on the development of the financial system by ensuring that banks are sufficiently liquid in order to be able to meet day-to-day withdrawals by depositors.

\footnotetext{
${ }^{42}$ As illustrated in table 3.

${ }^{43}$ A minimum of 3\% of deposits in the form of special Treasury bills remunerated at a rate of $6 \%$ and a minimum of $10 \%$ as a non-interest bearing current account.

${ }^{44}$ In December 2002, the BDL abolished interest paid on obligatory reserves exceeding $13 \%$.

${ }^{45}$ One of the prominent features of the Lebanese monetary economy is the strong dollarization of deposits and credits. The US dollar is taking the place in the collection of deposits and in the distribution of credit since the Lebanese pound was not, and is not filling its functions, mainly as a mean of payment or as a unit of account. This dollarization constitutes a serious brake to the financing of the growth and more closely, to the financing of the Lebanese industrial investment: economic agents in need of financing are indeed victims of a severe credit crunch in Lebanese pounds.

${ }^{46}$ The Central Bank Circulars: circular \#1949 dated September 20, 2001.

${ }^{47}$ Liquid assets $=$ cash and deposits in the central bank + net deposits in banks + treasury bills + accrued interest receivables.

The Central Bank circulars: circular \# 1709, dated March 18, 1999.

${ }^{48}$ Deposits and other obligations $=$ deposits to clients + public sector and related parties + transfers + engagement by acceptance + accrued interest payable + other credit accounts.

The Central Bank circulars: circular \# 1709, dated March 18, 1999.

${ }^{49}$ Fry M., (1995). Money, Interest and Banking in Economic Development. $2^{\text {nd }}$ edt. John Hopkins University Press: Baltimore MD

${ }^{50}$ Aschauer D., (1989). “Is public expenditure productive?” Journal of Monetary Economics 23: 177-200
} 


\section{Supply Of Credits To The Private Sector And Interest Rates}

With respect to the above diagnosis regarding the financial policies (interest rate restraints, reserve, and liquidity requirements) applied in Lebanon, we can deduce that this country is not financially "liberalized". In the first section of this paper, we tried to build a model that could fit the Lebanese limitations in order to measure the effects of financial liberalization on the supply of credit to the private sector. In this section, we will try to study the possibility of predicting these effects after adapting this model to the Lebanese equation.

The complete model is solved to derive the following result ${ }^{51}$ :

$\frac{\mathrm{d} \Delta L_{\mathrm{p}}}{\mathrm{d} i_{\mathrm{m}}}=\frac{\left(\alpha_{4}-\alpha_{24}\right)+\alpha_{44}\left(\alpha_{2}+\alpha_{22}\right)}{1+\alpha_{43}} \frac{\left.\alpha_{2}+\alpha_{22}\right)-\left(\alpha_{3}+\alpha_{23}\right)}{\left(\alpha_{2}\right)} \quad \gtrless 0$

Assuming that inflation is constant, a change in $\mathrm{i}_{\mathrm{m}}$ also reflects an equal change in the expected real rate on deposits, hence, the multiplier effect in (12) cannot be noticed. However, considering the case where the demand for government bonds remains constant, implying that $\alpha_{21}=----=\alpha_{28}=0$, equation (12) is reduced to:

$\frac{\mathrm{d} \Delta L_{\mathrm{p}}}{\mathrm{d} i_{\mathrm{m}}}=\frac{\alpha_{4}+\alpha_{2}}{1+\alpha_{2} \underline{\alpha}_{44}} \underline{\alpha}_{43}-\alpha_{3}$

It is obvious that denominator of (13) is positive ${ }^{52}$. As for the numerator, $\alpha_{2}$ and $\alpha_{4}$ are positive, but in fact the sign of $\alpha_{44}$ is indeterminate. It depends on combinations of a negative substitution effect and a positive income effect. In this adapted model, assumed that the negative substitution effect exceeds the positive income effect (please refer to table 2), implying that $\partial \mathrm{C} / \partial i_{\mathrm{m}}<0$ or that $\partial \mathrm{S} / \partial i_{\mathrm{m}}>0$. In this case, $\partial \Delta L_{\mathrm{p}} / \partial i_{\mathrm{m}}>0$, suggesting that in the absence of government borrowing from the banking sector, financial liberalization (as defined here) leads to an increase in the supply of bank credit to the private sector.

\section{Conclusion}

If the government finances its budget deficits by borrowing from the banking sector, it is a priori not possible to predict the effect of financial liberalization of the supply of credit to the private sector. In the absence of government borrowing from the banking sector, the effect is clearly determined, provided that consumption-saving is interest rate sensitive $\mathrm{e}^{53}$ or the consumption-saving decision is exogenous and has no bearing on the portfolio selection. The effect in both cases is positive.

Given the fact that the Lebanese government is highly depending on the banking sector to finance its growing deficit, the direct application of this model would not be able to predict the direct effects of the financial liberalization on the supply of credit to the private sector.

In fact, the average loan-to-asset ratio of the Lebanese banks since 1995 is only 31 percent $^{54}$. Unfortunately, cash and deposits with the BDL have tremendously increased in 2002. This increase isn't but the consequence of the absorption of the liquidity in local currency by the BDL and the cash contribution of banks (at a 0\% interest) to the financing of the Lebanese government in accordance with the decisions of Paris II. As a result, the share of loans

\footnotetext{
${ }^{51}$ See Gupta K. and Lensink R. (1996).

${ }^{52}$ Under extreme conditions this may be negative; for example, if $\left(1+\alpha_{2} \alpha_{43}\right)<\alpha_{3}$, in which case $\alpha_{3}$ will have to be sufficiently greater than unity, which is impossible.

${ }_{54}^{53}$ In the conventional sense, i.e., $\partial \mathrm{C} / \partial \mathrm{i}_{\mathrm{m}}<0$

${ }^{54}$ This ratio is unacceptable in the developed counties.
} 
allocated to the private sector is decreasing annually on average by $28 \%$ since 2001 , knowing that this decrease ${ }^{55}$ is not compensated via a direct financing through Beirut Stock Exchange market.

Table 4: Uses of Funds of Lebanese Commercial Banks

\begin{tabular}{|l|c|c|c|}
\hline In \% of Total Assets & $\mathbf{2 0 0 1}$ & $\mathbf{2 0 0 2}$ & September 2003 \\
\hline Cash \& Deposits at BDL & 14.8 & 15.1 & 28 \\
\hline Claims on Resident Private Sector & 30.9 & 28.8 & 25.9 \\
\hline Claims on Public Sector & 32.1 & 33.6 & 26.4 \\
\hline Foreign Assets & 18.1 & 18.1 & 15.7 \\
\hline Fixed Assets \& Other non-classified Assets & 4.1 & 4.4 & 4.0 \\
\hline
\end{tabular}

Source: Association of Banks in Lebanon, Annual Report, 2001-2002

\section{Illustrating the Crowding Out Effects}

In order to measure the crowding out effect due to the continuous government borrowing from the banking sector, we will identify first the relationship between the money supplied to the private sector and the interest rates.

Based on the monthly data ${ }^{56}$ covering the years $1995^{57}-2002$ (96 observations), the relationship between the money supplied to the private sector, MSPS, and the interest rates, I, (weighted average lending rate allocated by the commercial banks), is illustrated in the following equation:

MSPS $=82500.3^{58}-5198.5 \mathrm{I}$

$\mathrm{R}=0.928$ and $\mathrm{ARS}=0.859$

With respect to equation (1), we are able to identify the equilibrium levels of interest rates that correspond to the MSPS at the end of each period. Each equilibrium level represents the intersection between the supply of and the demand for money to the private sector. Assuming in this case that for each equilibrium level the MSPS is inelastic ${ }^{59}$, we should be able to deduce the demand function for money of the private sector, DMPS, where DMPS $=\mathrm{a}+\mathrm{bI}$. By substituting DMPS with the quantity of money where DMPS = MSPS, and "I" with their corresponding equilibrium levels, we can find the two parameters a and b. Consequently,

DMPS $=92710.84-6024.1 \mathrm{I}$

In a second step, we will determine the demand for money of the public sector in order to compare it with equation (2). The same methodology will be applied but instead, we will first, identify the relationship between the money supplied to the public sector, MSPub, and the interest rates served on TBs, and secondly, deduce the demand for money of the public sector, DMPub.

Based on the monthly data ${ }^{60}$ covering the years 1993-2002 (120 observations), the relationship between the MSPub and the interest rates served on TBs, $I_{\text {pub}}$, (weighted average interest rates on TBs) is illustrated in the following equation:

\footnotetext{
${ }^{55}$ Naimy V., (2004). “Overall Lebanese Banks' Performance: A Risk Return Framework”, The International Business And Economics Research Journal, Volume 4, Number 1, January, p. 1-10.

${ }_{57}^{56}$ Provided by the BDL and by the Ministry of Finance

${ }^{57}$ The years 1993 and 1994 are not covered because of the absence of official data concerning USD lending rates.

${ }^{58}$ For the quantity of money, figures are in billion of LP and for Article I, figures are in percentage.

${ }^{59}$ This restriction will allow us to determine the "forced" demand for credit of the PS.

${ }^{60}$ Provided by the BDL and by the Ministry of Finance
} 
$\mathrm{I}_{\text {pub }}=24.652-5 \mathrm{E}^{-04} \mathrm{MSPub}$

$\mathrm{R}=0.911$ and $\mathrm{ARS}=0.84$

Following the same methodology as above:

$\mathrm{DMPub}=49304-2000 \mathrm{I}_{\mathrm{pub}}$

The below figure compares the price that each sector was willing to pay to receive the same amount of credit, say the stock of the money supply available at the end of each period from 1993 through 2002.

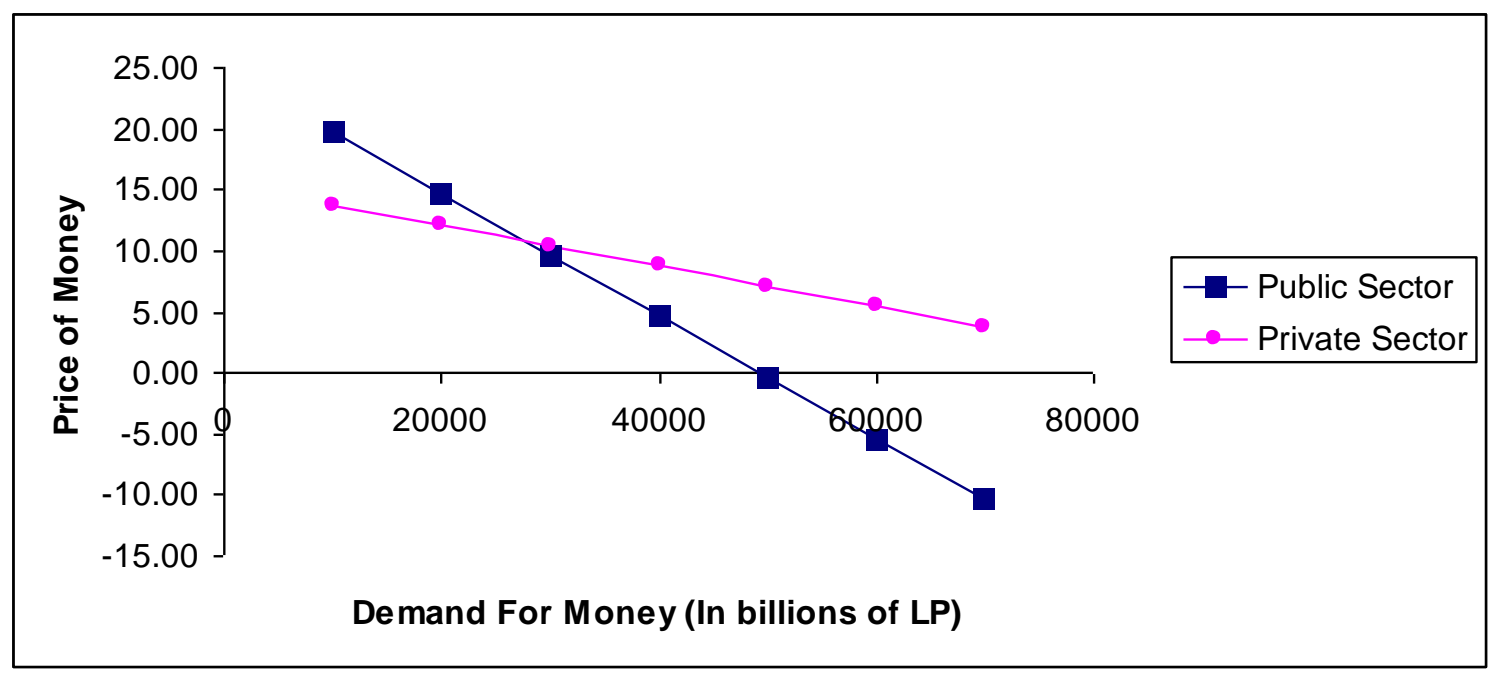

The high price that the private sector was willing to pay in order to have access to funds shows how much this sector is in need for financing and how much the government is having recourse to this fund to the detriment of the private sector. Lebanese banks appear like intermediary transferring deposits in LP and in USD to the public sector to finance an intolerable public deficit absorbing a fundamental part of the local financial resources.

\section{CONCLUSION}

This paper provides a systematic analysis of financial liberalization. A theoretical, adapted, and integrated model of portfolio decision-making and consumption-saving decision is conceived. This model constitutes a good foundation for future work dealing with financial liberalization and private investment and also with banking efficiency. It could be slightly modified to fit the constraints of any other developing country. In the case of Lebanon, the effect of financial liberalization cannot be accurately determined since the government is borrowing from the banking sector to off-set its budget deficits. Our findings demonstrate that financial liberalization is a much more complex process than has been assumed by earlier literature and its effects on the supply of credit to the private sector, on investment, and consequently on financial development are ambiguous. However, we were able to deduce the demand for money of the public and private sectors (under restrictive hypothesis) in order to illustrate the crowding out effects. The Lebanese government is financing its huge budget deficits through the sale of bonds to commercial banks. Therefore, these banks start rationing the available credit, where the private demand for loanable funds greatly exceeds the available supply. This situation is extremely damaging the financial and economic development of Lebanon. A drastic adjustment is urgently required via the adoption of a set of reforms dealing particularly with the implementation of a new structure of interest rates, a realistic exchange rate, and a fundamental change of the fiscal policy. 


\section{REFERENCES}

1. $\quad$ Aschauer D., (1989). “Is public expenditure productive?” Journal of Monetary Economics 23: 177-200

2. $\quad$ Barro R., (1984). Macroeconomics, Wiley, New York.

3. Bourguignon F., Branson W.H., et De Melo J., (1992). “ Adjustment and Income Distribution: A Micro-Macro Model for Counterfactual Analysis" Journal of Development Economics, 38: 17-39

4. Brainard W.C., et Tobin J., (1968). "Pitfalls in Financial Model Building" American Economic Review, 58: 99122.

5. Brillembourg A., (1978). "The Role of Savings in Flow Demand for Money: Alternative Partial Adjustment Models" Staff Paper FMI, 25:278-292.

6. Caprio G. (1994). "Banking on Financial Reform? A case of Sensitive Dependence on Initial Conditions." In Financial Reform: Theory and Experience, Caprio G, Atiyas I., Hanson J. (eds). Cambridge University Press.

7. Demetriades P., and Luintel K., (1997). "The Direct Cost of Financial Repression: Evidence from India". The Review of Economics and Statistics 106: 359-374

8. $\quad$ Fazzari S. M., Hubbard R.G., and Peterson B.C., (1988). "Financial Constraints and Corporate Investment." Brooking Papers on Economic Activity, (19): 141-195.

9. $\quad$ Fry M., (1995). Money, Interest and Banking in Economic Development. $2^{\text {nd }}$ edt. John Hopkins University Press: Baltimore MD

10. Gennote G., and Pyle D., (1991). "Capital Controls and Bank Risk”. Journal of Banking and Finance 15:805824.

11. Gertler M., Rose A (1996). "Finance, Public Policy and Growth”. In Financial Reform: Theory and Experience, Caprio G, Atiyas I., Hanson J. (eds). Cambridge University Press.

12. Gupta K. and Lensink R. (1996). "Financial Liberalization and Investment", Routledge Studies in Development Economics, British Library cataloguing in Publication Data.

13. Hellman T., Murdock K., Stiglitz JE., (1996a). "Financial Restraint: Toward A New Paradigm". In The Role Of Government In East Asian Economic Development: Comparative Institutional Analysis, Aoki M., OkunoFujiwara M., Kim H (eds). Oxford University Press: Oxford.

14. Hellman T., Murdock K., Stiglitz JE., (1996b). "Deposit Mobilization Through Financial Restraint”.. In Financial Development and Economic Growth, Hermes N., Lensink R (eds). Routlege: London.

15. Hellman T., Murdock K., Stiglitz JE., (2000). "Liberalization, Moral Hazard in Banking, and Prudential Regulation: Are Capital Requirements Enough?” American Economic Review 90: 147-165

16. Jappelli T. et Pagano M., (1994). "Savings, Growth and Liquidity Constraints." Quarterly Journal of Economics, 109(1): 83-109

17. Keely M., and Furlong F., (1990). "A reexamination of Mean-Variance Analysis of Bank Capital Regulation”. Journal Of Banking and Finance 14: 69-84.

18. Kim D and Santomero A., (1998). "Risk in Banking and Capital Regulation". The Journal of Finance XLIII:1219-1233

19. McKinnon R., (1973). Money and Capital in Economic Development. Brookings Institution, Washington DC.

20. Morisset J., (1993). "Does Financial Liberalization Really Improve Private Investment in Developing Countries?" Journal of Developing Economics, 40:133-150.

21. Naimy V. (2004), "Financing Problems Faced By The Lebanese SMEs: An Empirical Study". The International Business And Economics Research Journal, Volume 3, Number 1, January, p. 27-38

22. Naïmy V. (2004). "A proposed Restricting of Lebanese Public Debt To Promote Economic Growth". The International Business And Economics Research Journal, Volume 3, Number 8.

23. Naimy V., (2005). “Overall Lebanese Banks' Performance: A Risk Return Framework”, The International Business And Economics Research Journal, Volume 4, Number 1, January, p. 1-10.

24. Naïmy V. (2003). Marchés Emergents, financement des PME et croissance Economiques: Etude du cas libanais, NDU Press.

25. Net interest receipts are ignored (the change in real bank profits) since, according to Morisset (1993), the change in real bank profits is not influenced by changes in the deposit rate.

26. Owen P.D., (1981). "Dynamic Models of Portfolio Behavior: A General Integrated Model of Incorporating Sequential Effects", American Economic Review, 71:231-238. 
27. Pissarides C.A., (1978). "Liquidity Considerations in the theory of Consumption." Quarterly Journal of Economics 93: 279-296.

28. Rosenzweig M. R., and Wolpin K.I., (1993). "Credit Market Constraints, Consumption Smoothing and the Accumulation of Durable Production, Assets in Low-Income Countries: Investment in Bullocks in India." Journal of Political Economy, 101(2):223-244.

29. Rossi M., (1999). "Financial Fragility and Economic Performance in Developing Economies - Do Capital Controls, Prudential Regulation, and Supervision Matter?" IMF Working Paper, WP/99/66, International Monetary Fund: Washington, DC.

30. Shaw E., (1973). Financial Deepening in Economic Development Oxford University Press, New York.

31. Smith G., (1978). "Dynamic Models of Portfolio Behavior: Comment on Purvis." American Economic Review, 68:410-416.

32. Stiglitz JE. (1994). "The Role of the State in Financial Markets." Proceedings of the World Bank Annual Conference on Development Economics 1993, 19-52.

33. The Central Bank circulars: circular \# 1709, dated March 18, 1999.

34. The Central Bank Circulars: circular \#1949 dated September 20, 2001.

\section{NOTES}

